banking, trade, industry, the postal, tramway and railway services, teaching, health protection, journalism, science and art. About 125 millions live in villages, and of these about 10 millions are State-paid workers, and their dependants are employed on State-farms or in forestry or fishing.

Population has expanded by 30 per cent since pre-War days, but the production of food has failed to increase in a like proportion. Grain crops during the first five years period fell off owing to interna] struggles, but in 1933 and 1934 they increased to about 12 per cent over pre.War production. Grain consumption per head of the population, however, has now reached pre-War level, as export has ceased, whereas in pre-War days about 10 million tons of grain were exported annually. The production of potatoes has increased, but this is offset by a decrease in meat and milk. Housing in both towns and villages is very poor, and as yet little headway has been made. The lack of transport facilities is also very apparent. The European parts of the U.S.S.R. have $\mathbf{1 \cdot 3} \mathrm{km}$. of railways per sq. kilometre, whereas in the United States there are $4.3 \mathrm{~km}$. per sq. $\mathrm{km}$., despite the fact that the population density in that part of the U.S.S.R. is 30 per cent greater. The most developed part of the country, namely, the Ukraine, has a density of population nearly equal to that of France, but its railway system is less than one third the length. Moreover, all the railways are in poor condition, and the country is practically roadless.

\section{Rearmament in Germany}

THE question of the extent of Germany's rearmament has recently taken a prominent place in Parliamentary debates and in the public mind, and a number of exaggerated views have been put forward. In one case, for example, it was stated in the House of Commons that no less than $£ 1,500,000,000$ had been spent upon warlike preparation during Herr Hitler's regime, and that, in the year 1935 alone, 600-800 millions sterling was spent on armaments in Germany. It is undoubted that Germany has been rearming since 1934, but it is essential that Herr Hitler's programme should be viewed in its true setting and perspective, and to this end Prof. W. A. Bone has prepared a critical examination of the position in Germany based on financial and industrial statistics. This survey, which appeared in The Nineteenth Century and After of May, sets out the facts of Germany's industrial activity in the years 1929-35, and shows clearly that the output of those materials upon which armament manufacture chiefly depends-iron and steel, nickel, copper, chromium, tungsten and other non-ferrous metalsmerely reflects the slump between 1929 and 1932 followed by the regaining of lost ground to an extent slightly less than that which has taken place in Great Britain. From the analysis given, it is clear that Germany's rearmament, while a factor to be reckoned with, does not account for more than a fraction of the very large monetary sums which have been alleged to be involved.

\section{Indian Population of North America}

UNTIL recently, it would appear that little atten. tion has been given to certain facts relating to the Indian population of North America, which are disclosed in the census returns. It has generally been accepted that the Indian is a dying race; but it is now indicated that, while certain Indian peoples have undoubtedly become extinct, and the Indians of Mexico to a considerable extent have been fused in the general population, the Indian population north of Mexico as a whole is on the up grade. The problem of the future will be, not the arrest of a decrease, but the provision in the reservations of land adequate to support an increased population. This, at least, it is thought at the moment, is the form which the problem will take in the United States. Data relating to the population statistics were examined by Dr. Clark Wissler recently in a com. munication on the birth-rate among the Plains Indians, which was presented to the American Association of Physical Anthropologists meeting at New Haven, Conn., on April 30-May 2. Dr. Wissler then stated that the birth-rate of the Plains Indians would appear to be the highest in the world, being 48 per thousand. The white birth-rate, even before the depression, had sunk to 20 per thousand. He went on to point out that when the Indian was first placed on reservations, there was a rapid decline in numbers, but this had been checked. This was not due to the birth-rate, which apparently has not changed much since 1800 , but arose from a deathrate which reached its peak about 1890 and had since declined.

AN even more marked increase is shown by the figures relating to the Indian population of Canada, where between 1931, the census year, and 1934 when a rough count was made, the numbers rose from 108,000 to 112,000 . This high rate of increase is no doubt to be attributed largely to the vigilance in matters of hygiene, exercised by the Department of Indian Affairs, which, it is announced in a communication from the Ottawa correspondent of The Times in the issue of June 6, is to become a sub. ordinate branch of the new Ministry of Natural Resources. It is also stated that the trust fund which was created for the benefit of the Indians with whom treaties were made at the time of the acquisition from the Hudson Bay Company of the western territory beyond the Great Lakes, now amounts to $14,000,000$ dollars, while between $4,500,000$ dollars and $6,000,000$ dollars is spent on them annually out of public funds. These Indians live on reservations, and their affairs are managed by chiefs and councillors, who have certain restricted legislative rights. In Ontario and Quebec, however, most of the Indians live the life of ordinary Canadian citizens, being sometimes completely merged in the general population, with farms on the reserves. West of the Great Lakes where two thirds of the Indians live, and they have been less affected by the impact of white civilisation, they are much more dependent on the Government, owing to the 
inadequacy of their food supply now that the game, which was formerly their subsistence, has become scarce. Here the Department has embarked on an extensive educational programme in agriculture with a scheme of assistance, for which great success is claimed. Through it some hundreds of Indians have become entirely self-supporting by agriculture within two generations. About one third of the Indians still live the traditional nomadic life in the northern hinterland with the easily moved tepee as their home and hunting and trapping as their means of subsistence.

\section{Archæological Excavations in Syria}

SIR LEONARD WoOLIEY's account of the first month's work on the British Museum's new archæo. logical site in Syria fully confirms anticipation of the nature of the evidence likely to be obtained at such a point as the mouth of the Orontes, which must have been an important centre of international and commercial intercourse from early times. Tel Sheikh Yusuf el Gharib, a low mound, so called after a local saint, on the right bank of the Orontes, he reports in The Times of June 4, has produced evidence of nine occupation levels. As virgin soil has been reached just below deposits which are dated at about the twelfth century B.c., it is evident that the mound begins with what can only be a later extension of the main settlement. Although in consequence no material of Mycenæan age or earlier is forthcoming, it has yielded finds of considerable interest and no little importance. The pottery, for example, includes possibly the finest example of Proto-Corinthian ware yet known, while the so-called 'Cypriote' ware, a class of ceramics appearing in Cyprus in the Early Iron Age without known local antecedents, occurs here rather earlier in the eighth level in such sudden abundance as to suggest a violent occupation, and possibly may eventually afford a clue to the cultural origins of this type in Asia. Especially fine examples of orientalising Agean wares of the best sorts from the sixth and fifth levels, and innumerable fine fragments of Attic wares, belonging to the late sixth and fifth centuries B.c., some of which can be recognised as by known artists, from the fourth level point, in Sir Leonard's opinion, not only to a flourishing luxury trade with the Egean, but also to great enterprise on the part of the Athenians in establishing a flourishing commercial centre on this Asiatic coast at a time of tension with the great imperial power of Persia. Evidence was also obtained of intercourse with the Asiatic interior, the occurrence of a basalt bowl, showing a debased Hittite style in decoration, being noted. Such results in a restricted area afford abundant promise from future excavation.

\section{British Standards Institution}

THE annual general meeting of the British Standards Institution was held at the Institution of Mechanical Engineers on June 4, under the chairmanship of Mr. W. Reavell. In reporting on the progress of the work during his year of office, $\mathrm{Mr}$. Reavell made reference to the arbitration in con- nexion with the standards to be adopted in Great Britain for the $16-\mathrm{mm}$. sound films which, at the invitation of the General Council, Lord Riverdale had undertaken in February last, and the decision of which is now being loyally adopted throughout the industry. Mention was also made of the forth. coming visit of the director to New York and the Argentine in connexion with the work of the newly formed Argentine Institute for the Rationalisation of Materials. At the luncheon which followed the meeting, Lord Riverdale referred to the very economic manner in which the work is carried out, dealing as it now does with some eight hundred committees and more than a thousand meetings a year. Some people fear that standardisation means stagnation, but this is provided against in the precautions the B.S.I. takes when standards are brought into being and in the frequent review and revision of those standards. Industry does not fully appreciate the value of standardisation in the matter of capital expenditure. It means the possibility of reduction of stocks which in turn means liberating capital, and this might amount to millions of pounds in the British Empire.

Mr. E. J. Elford, the chairman for the forthcoming year, said that the British Standards Institution is greatly indebted not only to the Government for its continued financial support, to the many technical officers of the various Government departments for their assistance on the technical work, but also to the hundreds of representatives of industryusing that word in the widest sense who give their time and experience so willingly to this work of growing national importance. Mr. S. Tatchell, chairman of the Building Industries National Council, stressed the great importance to the building industry of the closest co-operation between his Council and the B.S.I., and referred to the agreements recently come to which have been set out in their Report on Standardisation Policy. Colonel Briggs, of Messrs. Unilevers, expressed the satisfaction of the chemical industry at the work already undertaken by the Institution in the chemical field and its desire to co-operate in future work of the Institution.

\section{The Development Fund}

THE twenty-fifth report of the Development Commissioners for the year ending March 1935 has now been published (London: H.M. Stationery Office. 2s. 6d. net). The function of the Commissioners is to make a thorough examination of applications for grants from the fund, amending or vetoing the schemes submitted if necessary, and afterwards to recommend to the Treasury what advances shall be made. The majority of the schemes aided call for recurrent expenditure, and as advances are made annually the progress of the work is kept under continuous review. Agriculture and rural economy comprise the main bulk of the expenditure, as under this heading come the regular grants to research institutes, advisory centres and rural industries, as well as the special grants, research scholarships and studentships. A short account of each institute is given, describing the type of work undertaken and 